\title{
Sea ice microbial communities. VIII. Bacterial production in annual sea ice of McMurdo Sound, Antarctica
}

\author{
Steven T. Kottmeier, Sarah McGrath Grossi \& Cornelius W. Sullivan \\ Marine Biology Research Section, Department of Biological Sciences, University of Southern California, Los Angeles, \\ California 90089-0371, USA
}

\begin{abstract}
Sea ice microalgae may contribute up to $50 \%$ of annual primary production in some regions of the Southern Ocean, but little is known of bacterial production in sea ice. Here we describe seasonal net accumulation (from microscopical direct counts), rate of 'instantaneous' growth (from ${ }^{3} \mathrm{H}$ thymidine incorporation), and importance of carbon production by bacteria in annual sea ice of McMurdo Sound during the 1982 austral spring and summer bloom of microalgae. Bacterial number and biomass increased less than 10 -fold in sea ice over a period of $2 \frac{1 / 2}{2}$ mo; yet bacterial cell production rate increased by more than 3 orders of magnitude. Bacterial growth increased throughout the microalgal bloom, but final bacterial biomass was less than $1 \%$ of microalgal biomass. Growth rates calculated from estimates of net accumulation of cells and thymidine incorporation were similar for congelation ice beneath $5 \mathrm{~cm}$ of snow and platelet ice beneath 0 to $5 \mathrm{~cm}$ of snow. Bacterial production (cell and carbon) lagged behind at first, but later paralleled the rate of primary production in sea ice. Bacterial carbon production was only $9 \%$ of primary production, while maximal rates of growth $(\mu=$ 0.02 to $0.2 \mathrm{~d}^{-1}$ ) were comparable to those reported for bacterioplankton of the Southern Ocean. Bacterial biomass and production in sea ice were equivalent to that found in several meters of underlying seawater. Significant correlations were found between bacterial production (cell, biomass, and thymidine incorporation per cell) and growth, and microalgal biomass, production, and growth, suggesting potential coupling between bacterial growth and microalgal photosynthetic metabolism in sea ice. We propose that the timing and amount of bacterial production in sea ice are dependent upon the growth phase of associated microalgae, the quantity and quality of EOC and compounds in the DOM pool available for bacterial growth, rates of bactivory and herbivory, and retention of the platelet ice layer and bottom layer of congelation ice. Further investigations into the fate of this bacterial production are needed to more fully determine the dynamic aspects of the microbial loop in sea ice.
\end{abstract}

\section{INTRODUCTION}

While the water column of ice-covered oceans may be seasonally depauperate in microbial biomass, sea ice provides several habitats for the growth of rich and diverse sea ice microbial communities (Bunt \& Wood 1963, Horner 1976, Whitaker 1977, Ackley et al. 1979, Sullivan \& Palmisano 1984). Distinct microbial communities composed of psychrophilic microalgae, bacteria, and protozoans colonize and grow in melt pools on the ice surface, in brine channels within the ice, attached to the bottom of the ice, and in the subice platelet layer (Ackley et al. 1979, Palmisano \& Sullivan $1985 a, b)$. Although sea ice microalgae may contribute from $10 \%$ (Hoshiai 1981) to $50 \%$ (Grossi et al. 1987) of annual primary production in some regions of the
Southern Ocean, little is known of bacterial production in sea ice (Sullivan 1985). We have proposed that a microbial loop functions within sea ice (Fig. 1) (Sullivan \& Palmisano 1984), similar to that proposed for seawater by Williams (1981) and Azam et al. (1983).

Bacteria in sea ice were first described by lizuka et al. (1966), who isolated Brevibacterium and Achromobacter species from surface meltwater near Syowa Station, Antarctica and incubated them at $25^{\circ} \mathrm{C}$. Sullivan \& Palmisano (1984) commented that growth of psychrophilic bacteria, i.e. those capable of growth at $0^{\circ} \mathrm{C}$ but not above $18^{\circ} \mathrm{C}$ (Morita 1975), would be prevented by such treatment. Among 155 bacterial strains isolated in our laboratory from various Antarctic habitats, $21 \%$ are psychrophilic (Kobori et al. 1984). Bacteria have since been observed in sea ice of the 


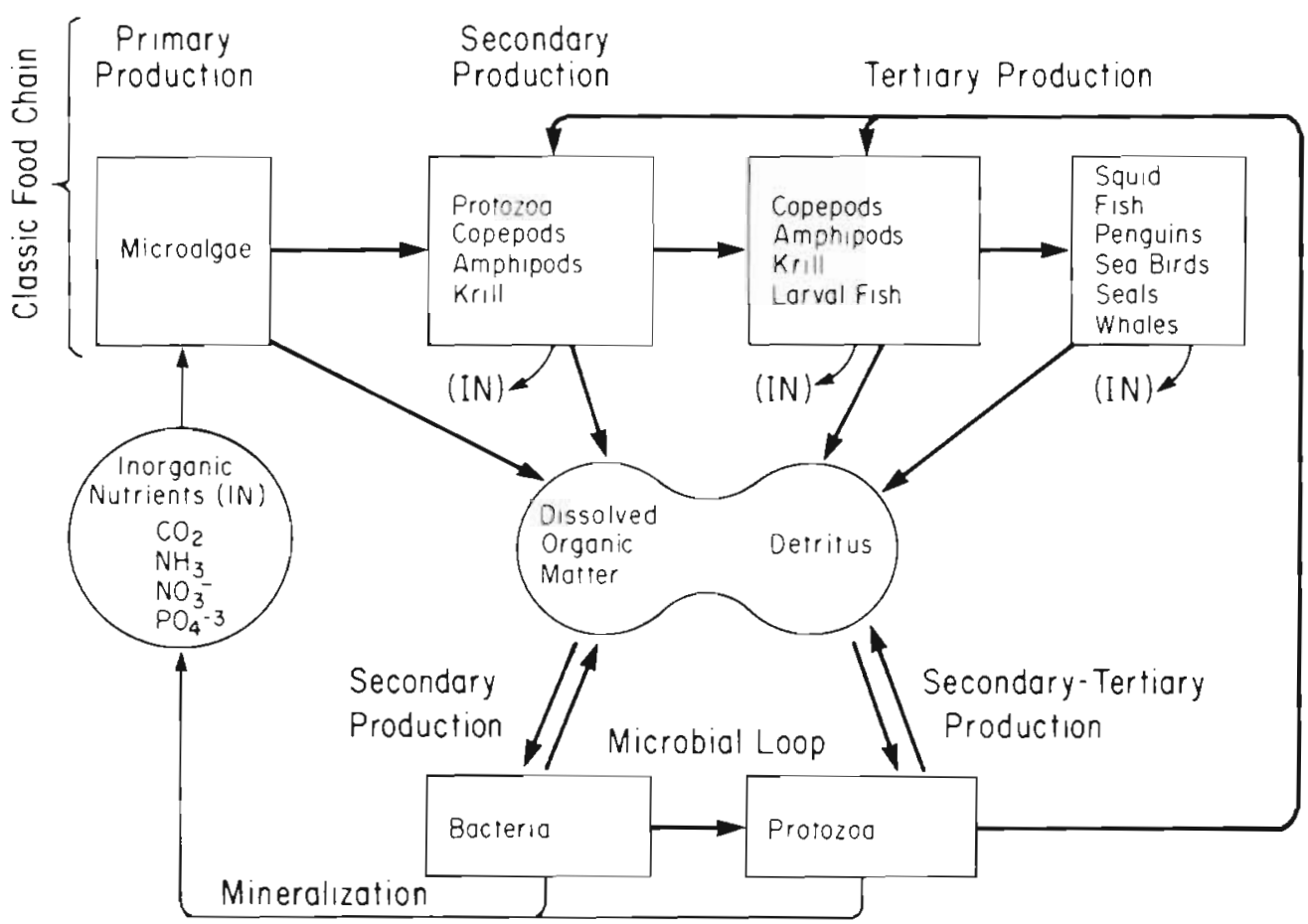

Fig. 1. Energy flow within the food web of Antarctic sea ice

Arctic (Horner 1976, Kaneko et al. 1977) and Antarctic (Bunt 1971, Sullivan \& Palmisano 1981, Marra et al. 1982, McConville \& Wetherbee 1983, Grossi et al 1984, Sullivan \& Palmisano 1984). The concentration of bacteria and bacterial biomass are enriched in pack ice relative to underlying seawater (Marra et al. 1982, Miller et al. 1984). In land-fast ice (congelation ice), nearly $50 \%$ of bacterial numbers and over $90 \%$ of bacterial biomass are located in the bottom $20 \mathrm{~cm}$ (Sullivan \& Palmisano 1984). Several morphological types are present (Sullivan \& Palmisano 1981, 1984, Marra et al. 1982), with free-living bacteria accounting for $70 \%$ of total bacterial biomass in congelation ice (Grossi et al. 1984).

It has been suggested that sea ice bacteria are frozen into the ice matrix and survive but do not grow (Kaneko et al. 1977). The presence of large, abundant, and morphologically distinct sea ice bacteria, however, implies an active heterotrophic community (Sullivan \& Palmisano 1981, 1984, Marra et al. 1982). Observations of dividing cells (Sullivan \& Palmisano 1984), cells which incorporate radiolabeled organic substrates under simulated in situ conditions (Sullivan et al. 1985), and a direct increase of bacterial numbers with microalgal numbers during a spring and summer bloom (Grossi et al. 1984, Sullivan et al. 1985), further suggest that bacteria actively grow in sea ice. Here we describe the seasonal net accumulation, rate of growth, and importance of carbon production by bacteria during the austral spring and summer bloom of micro- algae in annual sea ice of McMurdo Sound, Antarctica. Companion papers describe the primary production (Grossi et al. 1987) and downwelling irradiance (Palmisano et al. 1987) of this area.

\section{METHODS}

Sample collection and determination of bacterial biomass. Samples of sea ice were taken from the site of a light perturbation experiment from 8 October to 26 December 1982. Cores of congelation ice from each quadrat were taken and treated as described in Grossi et al. (1987) to quantify bacterial number and biomass by direct counts of DAPI $(4,6$-diamidino-2-phenylindole $2 \mathrm{HCl}$, Sigma) stained specimens as described elsewhere (Grossi et al. 1984). Bacterial biovolumes were estimated from cell dimensions (Zimmerman 1977) and biomass derived from biovolume using a conversion factor of $220 \mathrm{fg} \mathrm{C} \mathrm{mm}^{-3}$ (Bratbak \& Dundas 1984). Samples of platelet ice were collected by divers under the layer of congelation ice using $8 \mathrm{l}$ jars with lids (Nalgene) and treated as described above for the congelation ice. Samples of the water $3 \mathrm{~m}$ beneath the ice were taken using a Kemmerer PVC water sampler (Wildco) that was pre-rinsed with $95 \%$ ethanol prior to use.

Determination of chlorophyll $a$ and phaeopigments. Samples of water collected from $3 \mathrm{~m}$ beneath the sea ice were filtered through GF/C filters (Whatman); fil- 
ters were frozen at $-20^{\circ} \mathrm{C}$ until extraction. Filters were extracted in $90 \%$ acetone and analyzed fluorometrically following the method of Strickland \& Parsons (1972).

In situ bacterial production. Concurrent with the assay of primary production in sea ice and seawater (Grossi et al. 1987), bacterial production was measured in $125 \mathrm{ml}$ polymethylpentene wide-mouth jars (Nalgene) fitted with serum stoppers on the lids. In an effort to retain the structure of the microbial community and ice microenvironment, the bottom $5 \mathrm{~cm}$ of each core of congelation ice was quartered by ice saw (yielding approximately $40 \mathrm{ml}$ of ice) and suspended in 50 to $75 \mathrm{ml}$ of seawater in each jar. In parallel, ice platelets were placed in jars with 50 to $75 \mathrm{ml}$ of interstitial platelet water. Samples of seawater $(100 \mathrm{ml})$ were dispensed into sterile $150 \mathrm{ml}$ serum stoppered bottles. Control jars and bottles consisted of replicate samples killed by addition of borate-buffered formalin to yield a final concentration of $1 \%$. [Methyl- ${ }^{3} \mathrm{H}$ ] thymidine (New England Nuclear) (sp. act., 3.07 TBq mmole $^{-1}$ ) was initially taken to dryness under $\mathrm{N}_{2}$, rehydrated in unlabeled thymidine (Sigma) made up in distilled water, and filter-sterilized $(0.22 \mu \mathrm{m})$ with a Millex unit (Millipore) into a sterile polypropylene test tube (Falcon). This eliminated volatile ${ }^{3} \mathrm{H}$ by-products that form by exchange with the high specific activity [methyl- ${ }^{3} \mathrm{H}$ ] thymidine. To each jar or bottle [methyl${ }^{3} \mathrm{H}$ ]thymidine was added to obtain a final concentration of $10 \mathrm{nM}\left(7.4 \mathrm{kBq} \mathrm{ml} l^{-1}\right)$. Jars were placed in a Plexiglass manifold and bottles on a line and repositioned by divers where the samples were taken, for in situ incubation of 24 to $36 \mathrm{~h}$. Previous microautographic evidence has demonstrated incorporation of ${ }^{3} \mathrm{H}$-thymidine only by bacteria during long (12 to $24 \mathrm{~h}$ ) incubations at low irradiance and temperatures (Sullivan et al. 1985), suggesting that nucleic acid synthesis takes place under in situ conditions in the ice. Incubation was terminated by injection of boratebuffered formalin through the serum stopper to yield a final concentration of $1 \%$. Sea ice in jars was allowed to melt at room temperature in the dark for 1 to $3 \mathrm{~h}$, while seawater samples were kept at $0^{\circ} \mathrm{C}$ in the dark until extraction with trichloroacetic acid (TCA). Samples were taken from each jar or bottle for determination of bacterial biomass as described above. Incorporation of thymidine into cold $\left(0^{\circ} \mathrm{C}\right)$ TCA-insoluble material was determined according to the method of Fuhrman \& Azam (1980), using $0.2 \mu \mathrm{m}$ pore size Nuclepore filters. Dilution of congelation ice samples by seawater was corrected by subtraction of thymidine incorporation in seawater, while ice platelet samples were corrected to a $20 \%$ ice platelet: $80 \%$ interstitial platelet water ratio (Bunt \& Lee 1970, authors' unpubl. obs.). Bacterial cell production was calculated from a conversion factor of $4 \times 10^{18}$ cells per mole of thymidine incorporated. Use of this conversion factor yields an approximate yet conservative estimate of bacterial cell production, since the factor has recently bcen reported to range from 4 to $60 \times 10^{18}$ cells per mole of thymidine incorporated ( $\mathrm{H}$. Ducklow pers. comm.). Bacterial carbon production was determined from cell production and average cell biomass estimated by epifluorescence microscopy. Bacterial production per $\mathrm{m}^{2}$ of sea ice was based on either a $5 \mathrm{~cm}$ thick core of congelation ice or depth of the platelet ice layer measured by divers. Expressing production on an areal basis is the only reasonable basis of comparing congelation and platelet ice as well as production from other regions of the world's oceans (Palmisano \& Sullivan 1985b) moreover $90 \%$ of bacterial biomass occurs in the bottom of congelation ice (Sullivan \& Palmisano 1984).

Estimates of bacterial growth $(\mu)$ and generation time $(\mathrm{g})$. Instantaneous rate of bacterial growth $\left(\mu_{\mathrm{in}}\right)$ was estimated using the equation:

$$
\mu_{\mathrm{n}}=\frac{1}{\mathrm{t}} \ln \left(\frac{\text { thy/cell }+\Delta{ }^{3} \mathrm{H} \text {-thy/cell }}{\text { thy/cell }}\right)
$$

where $\mu_{\mathrm{in}}=$ growth rate $\left(\mathrm{d}^{-1}\right) ; \mathrm{t}=1 \mathrm{~d}$; thy/cell $=$ thymidine incorporated per cell (ratio $=2.50 \times 10^{-19}$ mole of thymidine per cell: inverse of thymidine to cells conversion factor described above); $\Delta{ }^{3} \mathrm{H}$-thy/cell $=$ daily rate of ${ }_{3} \mathrm{H}$-thymidine incorporation. This equation is derived from Eppley (1972) and modified for specific growth rate $(\mu)$ of bacteria. 'Net' rate of bacterial growth $\left(\mu_{\text {net }}\right)$ (accumulation in sea ice) was calculated from direct microscopical counts using the equation reported by Grossi et al. (1984):

$$
\mu_{\text {net }}=\frac{\ln N_{1}-\ln N_{1}}{t}
$$

where $N_{j}$ and $N_{i}=$ initial and final standing crops respectively; $\mathrm{t}=$ time in $\mathrm{d}$. Generation time $(\mathrm{g})$ in $\mathrm{d}$ was calculated from the equation:

$$
g=\frac{0.693}{\mu}
$$

\section{RESULTS}

Bacterial number and biomass increased only slightly in sea ice regardless of its snow cover (Fig. $2 \mathrm{~A}$ to D), attaining $10^{10}$ to $10^{11}$ cells $\mathrm{m}^{-2}$ and 0.4 to $3.8 \mathrm{mg}$ $\mathrm{C} \mathrm{m}^{-2}$ respectively. Bacterial number and biomass were nearly equal in the bottom of congelation ice and in the platelet ice layer. By mid-December, there was little difference in bacterial number or biomass versus 

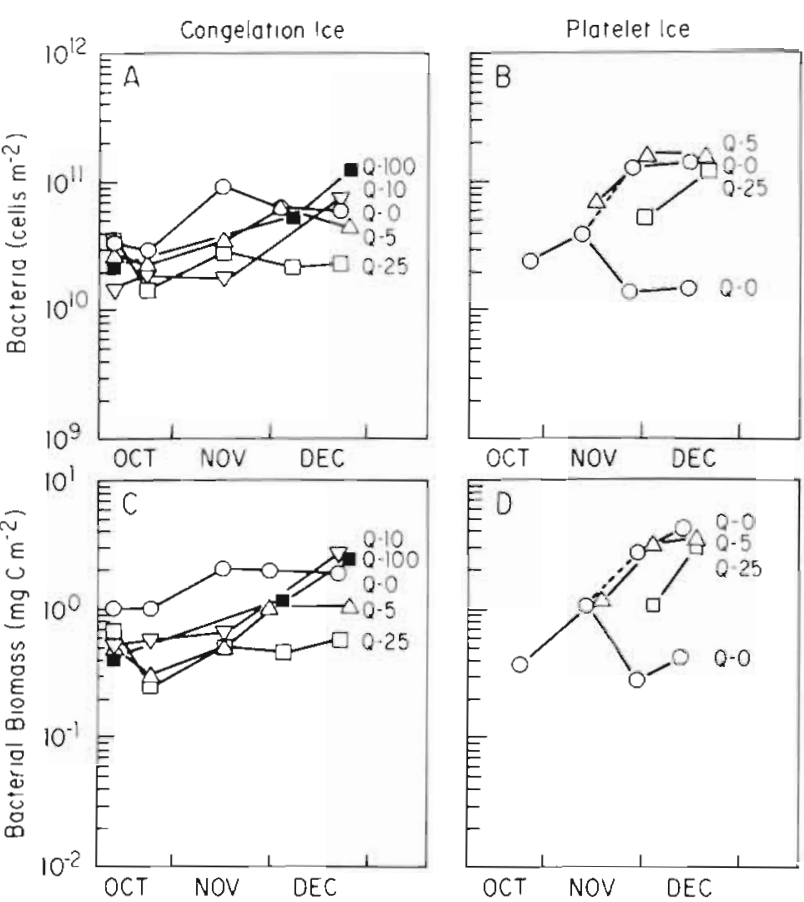

Fig. 2. ( $A, B)$ Bacterial number and $(C, D)$ biomass in $(A, C)$ congelation ice (bottom $20 \mathrm{~cm}$ and subsequent accreted layers) and $(B, D)$ platelet ice beneath variable snow cover. $Q-0$, Q-5, Q-25, and $\mathrm{Q}-100$ refer to $100 \mathrm{~m}^{2}$ quadrats of congelation ice covered with no snow, $5 \mathrm{~cm}$ of snow, $25 \mathrm{~cm}$ of snow, and $100 \mathrm{~cm}$ of snow respectively. Dotted line for Q-0 represents integrated bacterial number and biomass in surviving clusters of platelets following onset of melting in mid-Nov; solid line for Q-0 reflects loss of $90 \%$ of platelet layer and associated bacteria

snow cover in the platelet ice layer, except for snowfree ice. When averaged over the total area of the quadrat, bacterial number and biomass were 10 -fold less due to melting of $90 \%$ of the platelet ice layer during late November. Melting was presumably mediated by microalgae (Sullivan et al. 1985, Grossi et al. 1987). Surviving clusters of platelets exhibited bacterial number and biomass similar to sea ice covered with up to $25 \mathrm{~cm}$ of snow. In early October, bacterial concentrations in the bottom $20 \mathrm{~cm}$ of congelation ice ranged from 0.7 to $1.5 \times 10^{11}$ cells $\mathrm{m}^{-3}$ of ice meltwater (Fig. 3). By mid-December, bacterial concentrations ranged from 0.6 to $2.5 \times 10^{11}$ cells $\mathrm{m}^{-3}$ for the same $20 \mathrm{~cm}$ section of ice, and as high as $1.4 \times 10^{12}$ cells $\mathrm{m}^{-3}$ for ice that accreted below. Bacterial concentrations in the platelet layer ranged from 1.5 to $3.3 \times 10^{11}$ cells $\mathrm{m}^{-3}$ and in the underlying seawater from 0.25 to $2.5 \times$ $10^{11}$ cells $\mathrm{m}^{-3}$.

Daily rates of bacterial cell production and thymidine incorporation per cell in sea ice exhibited logarithmic increase during the study. Bacterial cell production rates in congelation ice lagged behind that in the platelet layer (Fig. 4A). Snow-free platelet ice

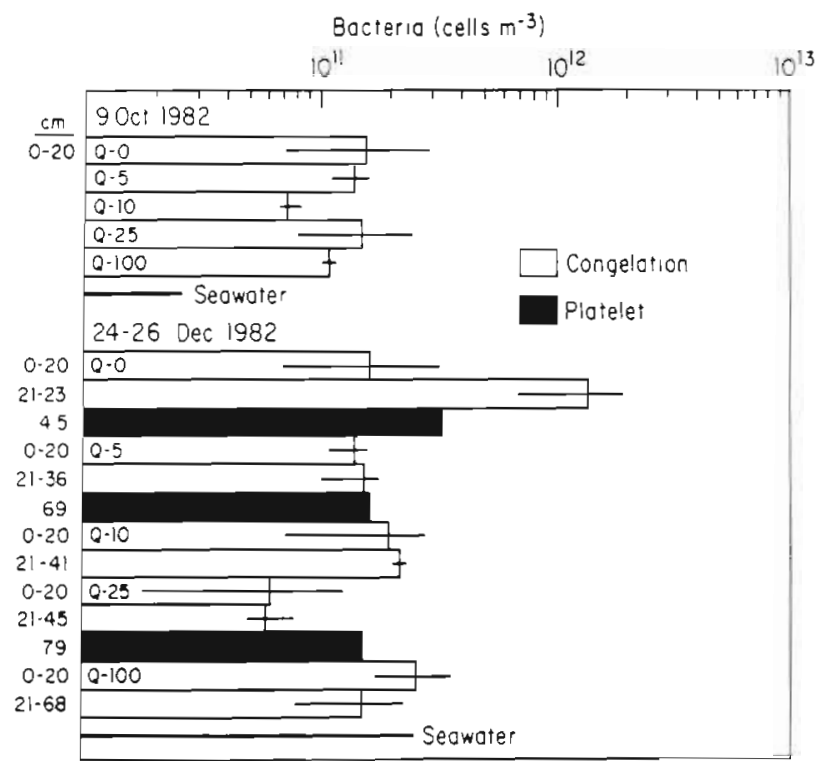

Fig. 3. Concentrations of bacteria at beginning and end of 2.5 mo experiment. Bacterial concentrations shown are from samples taken from the bottom $20 \mathrm{~cm}$ of congelation ice and underlying seawater at $3 \mathrm{~m}$ on 9 Oct 1982; and from same $20 \mathrm{~cm}$ section and subsequent accreted layer of congelation ice, platelet ice, and underlying seawater on 24 to 26 Dec 1982

had 10 -fold lower bacterial production rate per $\mathrm{m}^{2}$ (averaged over the area of the quadrat) after midNovember due possibly to melting and loss of the platelet layer as described above. Longer lags in bacterial production rate occurred with increased snow cover. By mid-December bacterial production rate was similar in platelet ice regardless of snow cover, while congelation ice exhibited lower production with increased snow cover. A similar trend was also found for thymidine incorporation rate per cell (Fig. 4B).

The rate of bacterial carbon production (secondary production) in sea ice also exhibited a logarithmic increase, except in congelation ice covered with 5 and $25 \mathrm{~cm}$ of snow (Fig. 4C), where it was lower. Bacterial carbon production was 2 to 5 orders of magnitude less than primary production (Fig. 4D). Although a significant positive relation was found between log bacterial carbon production and log primary production $\left(\mathrm{r}^{2}=\right.$ 0.34, $\mathrm{p}<0.01$ ) (Rohlf \& Sokal 1969, Sokal \& Rohlf 1981), it explained only $34 \%$ of the variability in the data.

In seawater $3 \mathrm{~m}$ beneath sea ice, the concentration and biomass of bacterioplankton increased an order of magnitude from $10^{10}$ to $10^{11}$ cells $\mathrm{m}^{-3}$ and from 0.6 to $4.7 \mathrm{mg} \mathrm{C} \mathrm{m} \mathrm{C}^{-3}$ from late October to early November (Fig. 5A). Chlorophyll $a$ and phaeopigments increased steadily by 2 orders of magnitude from 0.002 to $0.57 \mathrm{mg}$ $\mathrm{m}^{-3}$ and from 0.005 to $0.085 \mathrm{mg} \mathrm{m}^{-3}$ respectively during the study (Fig. 5B). 

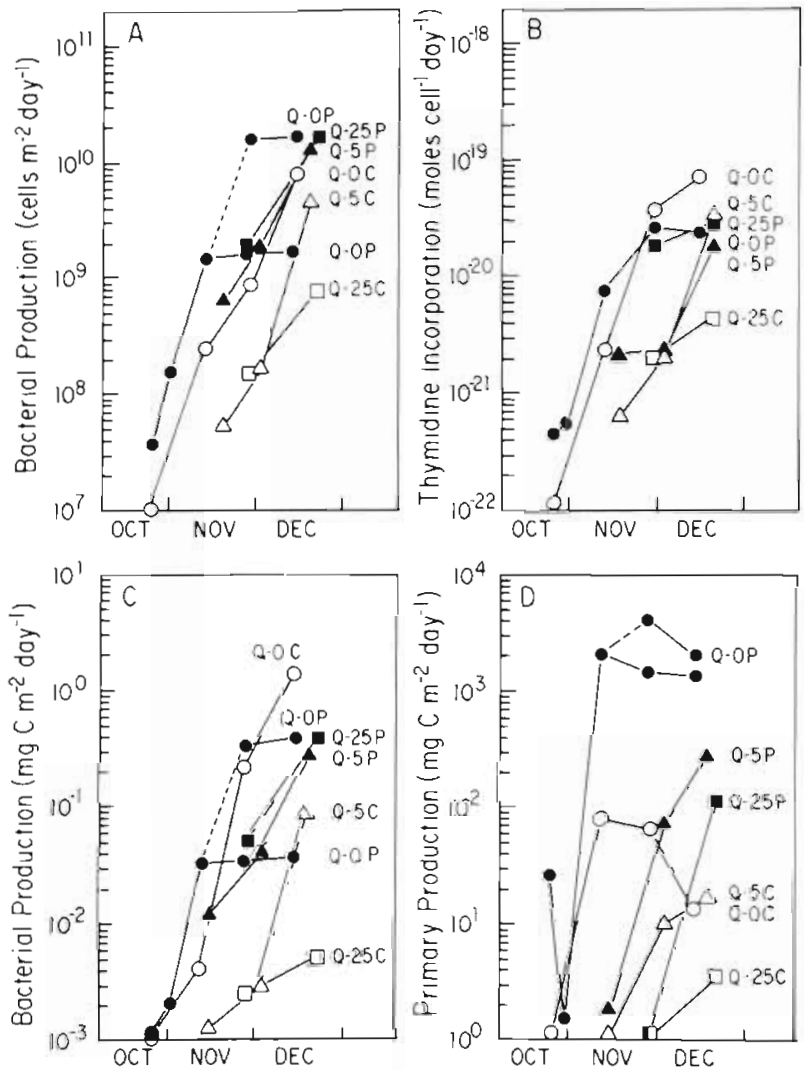

Fig. 4. (A) Bacterial cell production, (B) thymidine incorporation per bacterial cell, (C) bacterial carbon production, and (D) microalgal primary production in sea ice beneath variable snow cover ( $\mathrm{m}^{-2}$ and $\mathrm{m}^{-3}$ based on bottom $5 \mathrm{~cm}$ for congelation ice [C] and depth of platelet ice [P] layer). Microalgal primary production taken from data in Table 4 of companion paper by Grossi et al. (1987)

Bacterioplankton cell production rates also increased 2 orders of magnitude from $10^{8}$ to $10^{10}$ cells $\mathrm{m}^{-3} \mathrm{~d}^{-1}$ and from $10^{-3}$ to $10^{-1} \mathrm{mg} \mathrm{C} \mathrm{m}^{-3} \mathrm{~d}^{-1}$ during the study (Fig. 5C). Primary production in seawater remained quite low until onset of a Phaeocystis sp. bloom in late December, when it increased from 1 to
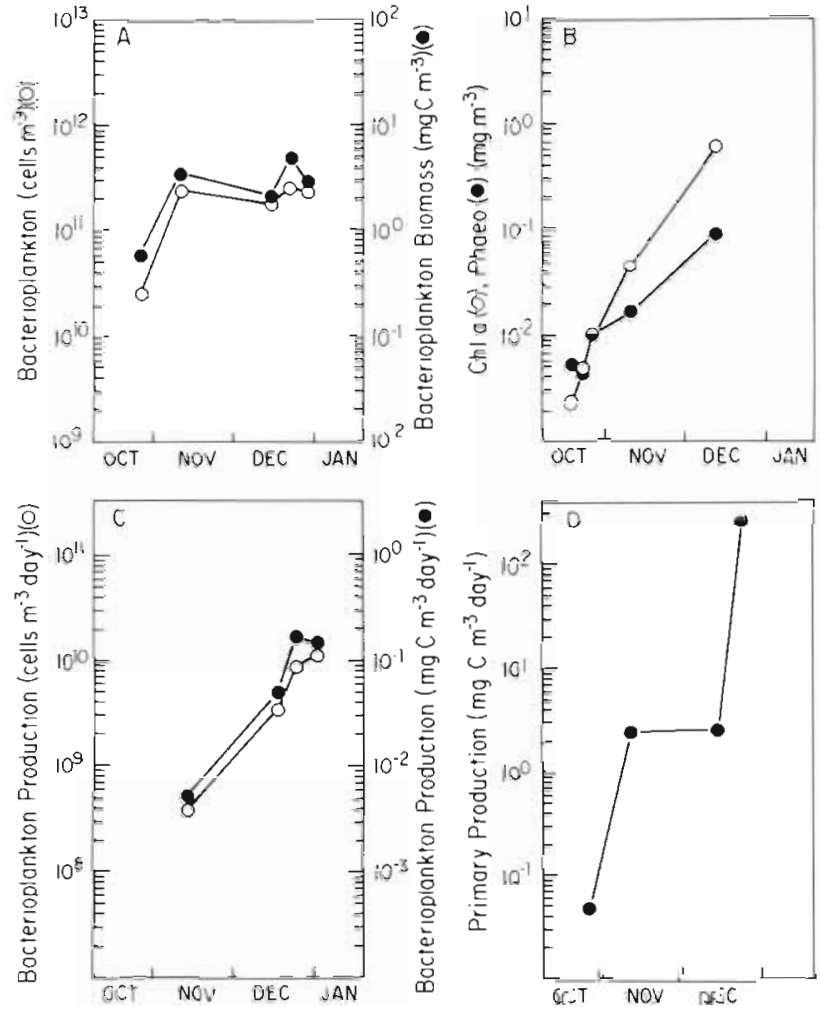

Fig. 5. (A) Bacterioplankton number and biomass, (B) phytoplankton chlorophyll a and phaeopigments, (C) bacterioplankton cell and carbon production, and (D) phytoplankton primary production in seawater $3 \mathrm{~m}$ beneath sea ice of the study site. Phytoplankton primary production taken from Grossi (1985) and Grossi et al. (1987)

over $100 \mathrm{mg} \mathrm{C} \mathrm{m}^{-3} \mathrm{~d}^{-1}$ in a few days (Fig. 5D) (Grossi 1985).

Bacterial growth rate $\left(\mu_{1 n}\right)$ increased 10 to 100 -fold in sea ice (Fig. 6A, B). Growth rate in congelation ice exhibited an inverse relation with snow cover, increasing from less than $0.01 \mathrm{~d}^{-1}$ in mid-November to 0.24 , 0.12 , and $0.02 \mathrm{~d}^{-1}$ in mid-December for ice covered with 0,5 , and $25 \mathrm{~cm}$ of snow respectively. No similar relation was found in the platelet ice layer, where $\mu_{\text {in }}$
Fig. 6. Rate of bacterial growth $\left(\mu_{n}\right)$, calculated from ${ }^{3} \mathrm{H}$-thymidine incorporation, for sea ice and seawater $3 \mathrm{~m}$ beneath sea ice at the study site. (O) Q-0; $(\triangle)$ Q-5; ( $\square)$ Q-25
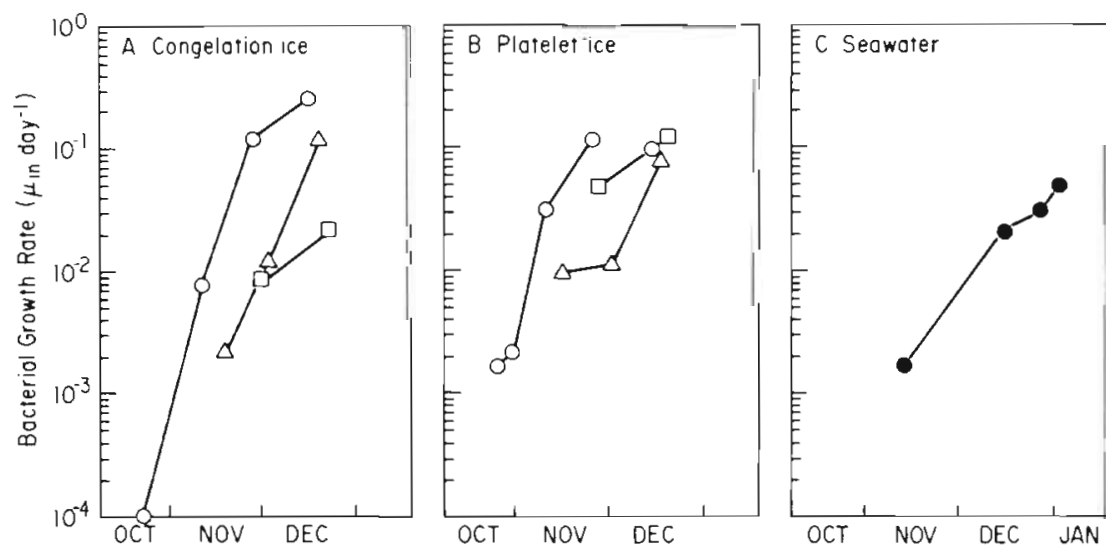
was $0.08,0.07$, and $0.12 \mathrm{~d}^{-1}$ in mid-December for ice covered with 0,5 , and $25 \mathrm{~cm}$ of snow respectively. Growth rate of bacterioplankton increased 100 -fold from 0.002 to $0.03 \mathrm{~d}^{-1}$ in late December during onset of a Phaeocystis sp. bloom (Fig. 6C).

Spearman rank correlations were calculated for a number of parameters measured during assays of secondary and primary production in sea ice (Tate \& Clelland 1957). Significant correlations $(p<0.05)$ were found between bacterial production (cell, biomass, and thymidine incorporation per cell) and growth, and microalgal biomass, production, and growth (Table 1).

Two estimates of bacterial growth in sea ice, net accumulation (from direct microscopical cell counts) and instantaneous rate of growth (from ${ }^{3} \mathrm{H}$-thymidine incorporation) were compared for sea ice covered with 0 and $5 \mathrm{~cm}$ of snow from mid-November to midDecember (Table 2). Unlike in the companion paper on growth and primary production by Grossi et al. (1987), these estimates do not account for an overall $90 \%$ loss of the ice platelet layer in snow-free ice. Instead, they reflect the $45 \mathrm{~cm}$ thickness of the platelets surviving in
mid-December. In congelation ice without snow cover, no net increase in bacterial number was found from direct counts, while ${ }^{3} \mathrm{H}$-thymidine incorporation suggested 0.2 to $7.3 \times 10^{9}$ cells $\mathrm{m}^{-2} \mathrm{~d}^{-1}$. This represents a daily input of 0.3 to $8.6 \%$ of the standing crop of 6 to $8.5 \times 10^{10}$ cells $\mathrm{m}^{-2}$. The thymidine estimate of cell increase bracketed the direct count estimate in congelation ice covered with $5 \mathrm{~cm}$ of snow and platelet ice covered with 0 and $5 \mathrm{~cm}$ of snow. The thymidine estimate of growth rate yielded lower values, however, than those estimated from direct counts.

\section{DISCUSSION}

Bacteria increase in number and biomass in annual sea ice (Grossi et al. 1984, Sullivan et al. 1985), but estimates of their growth rate and relative importance to water column productivity have not been described until now. The results of our in situ experiments conducted over a $2 \frac{1 / 2}{2}$ mo period, based upon microscopic direct counts (rate of net accumulation) and incorpora-

Table 1. Spearman rank correlation matrix for parameters measured during determination of secondary and primary production All values significant $(p<0.05)$ except those marked ns (not significant)

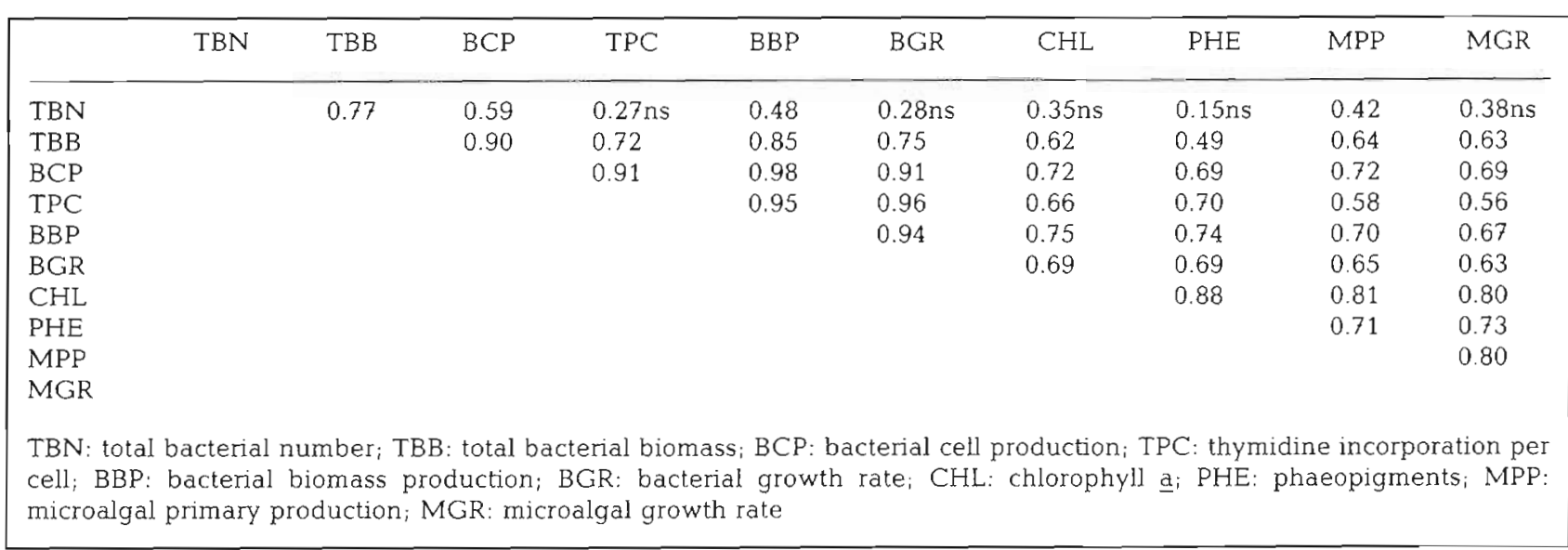

Table 2. Two different estimates of bacterial cell production, specific growth rate, and generation time in sea ice near Cape Armitage, McMurdo Sound, Antarctica from mid-November to mid-December 1982

\begin{tabular}{|c|c|c|c|c|c|c|c|c|c|}
\hline \multirow{3}{*}{ Ice/snow cover } & \multicolumn{3}{|c|}{ Net accumulation (direct count) } & \multicolumn{6}{|c|}{ Instantaneous growth ( ${ }^{3} \mathrm{H}$-thymidine incorp.) } \\
\hline & \multirow[t]{2}{*}{$\begin{array}{c}\text { Net increase } \\
\left(10^{9} \text { cells } \mathrm{m}^{-2} \mathrm{~d}^{-1}\right)\end{array}$} & \multirow[t]{2}{*}{$\begin{array}{l}\mu_{\text {net }} \\
\left(d^{-1}\right)\end{array}$} & \multirow[t]{2}{*}{$\begin{array}{l}g_{\text {net }} \\
\text { (d) }\end{array}$} & \multicolumn{2}{|c|}{$\begin{array}{c}\text { Net increase } \\
\left(10^{9} \text { cells } \mathrm{m}^{-2} \mathrm{~d}^{-1}\right)\end{array}$} & \multicolumn{2}{|c|}{$\underset{\left(\mathrm{d}^{-1}\right)}{\mu_{\mathrm{in}}}$} & \multicolumn{2}{|c|}{$\begin{array}{l}g_{i n} \\
(d)\end{array}$} \\
\hline & & & & Nov & Dec & Nov & Dec & Nov & Dec \\
\hline \multicolumn{10}{|l|}{ Congelation } \\
\hline $0 \mathrm{~cm}$ & 0 & - & - & 0.2 & 7.3 & 0.007 & 0.2 & 90 & 3 \\
\hline $5 \mathrm{~cm}$ & 0.3 & 0.8 & 0.9 & 0.05 & 4.1 & 0.002 & 0.1 & 294 & 6 \\
\hline \multicolumn{10}{|l|}{ Platelet } \\
\hline $0 \mathrm{~cm}$ & 3.8 & 0.8 & 0.8 & 1.4 & 15.6 & 0.03 & 0.08 & 24 & 8 \\
\hline $5 \mathrm{~cm}$ & 2.7 & 0.8 & 0.8 & 0.6 & 12.2 & 0.009 & 0.07 & 77 & 10 \\
\hline
\end{tabular}


tion of ${ }^{3} \mathrm{H}$-thymidine (rate of instantaneous growth), demonstrate that bacteria not only accumulate, but also grow in the bottom layer of hard congelation ice and underlying layer of loosely consolidated platelet ice. Rates of growth and production by this concentrated bacterial community in the sea ice increase logarithmically during the prolonged microalgal bloom of spring and summer. Bacterial production in sea ice was equivalent to that found in several meters of underlying seawater (Kottmeier et al. 1984).

Bacteria accumulated in the bottom $20 \mathrm{~cm}$ plus accreted layer of congelation ice and the platelet ice layer in concentrations from 0.2 to $1.4 \times 10^{12}$ cells m$^{-3}$ of ice meltwater, a range comparable to that reported by Sullivan \& Palmisano (1984) for congelation ice. Since these cells live mainly in the small volume of liquid brine in congelation ice, estimated to be 5 to $12 \%$ by volume (Golden \& Ackley 1981), and between ice crystals in interstitial water of platelet ice, estimated to be $80 \%$ by volume (Bunt \& Lee 1970), their in situ concentrations may be as high as $2.8 \times 10^{13}$ cells $\mathrm{m}^{-3}$. Similar concentrations have also been found for pack ice of the Weddell Sea during October to December (Marra et al. 1982, Miller et al. 1984).

Bacteria did not accumulate as markedly in 1982 sea ice composed of congelation plus platelet ice as reported for 1981 congelation ice by Grossi et al. (1984). Unlike microalgal numbers, biomass, and rates of primary production, which were significantly higher in sea ice with reduced snow cover and consequently more light (Grossi et al. 1987), there were less obvious trends in bacterial number and biomass versus snow cover. Bacterial biomass represented only a small fraction of microalgal biomass in sea ice. If one assumes a microalgal carbon to chlorophyll a ratio of 38 (Sullivan et al. 1985), then accumulated bacterial biomass was less than $1 \%$ of microalgal biomass. This is much lower than the 10 to $40 \%$ reported for bacterioplankton in the world's oceans (Ducklow 1983).

The 2 estimates of bacterial growth, net accumulation and instantaneous growth, were not exactly comparable for congelation ice since they were not based upon the same thickness of ice. Bacterial growth from net accumulation was based upon assumptions made in our earlier work (Grossi et al. 1984), using the initial bottom $20 \mathrm{~cm}$ of congelation ice, which is enriched in bacterial number and biomass (Sullivan \& Palmisano 1984), and subsequent accreted ice representing 3 to $50 \mathrm{~cm}$ of additional ice by mid-December (Grossi et al. 1987). Bacterial growth rates estimated from thymidine incorporation were based on only the bottom $5 \mathrm{~cm}$ of congelation ice and may potentially underestimate bacterial production when compared to net accumulation. However, we reasoned that the bottom $5 \mathrm{~cm}$ of congelation ice represented the region of most actively growing bacteria, in part based upon arguments presented by Grossi \& Sullivan (1985). Presumably this layer is flushed convectively with underlying seawater (Reeburgh 1984) and has temperatures close to the $-1.9^{\circ} \mathrm{C}$ of the seawater (Littlepage 1965, Kottmeier et al. 1985). Flushing may provide fresh nutrients to the layer for microbial growth, a mechanism for colonization of congelation ice by microorganisms, and warmer temperatures for microbial growth. Although brine tubes and chambers penetrate several $\mathrm{cm}$ up into congelation ice (Lake \& Lewis 1970) and probably contain bacteria (Sullivan \& Palmisano 1984), these cells would be exposed to concentrated brines having little exchange with the underlying seawater and temperatures generally colder than $-1.9^{\circ} \mathrm{C}$ (Kottmeier et al. 1985). These conditions would presumably preclude significant bacterial growth. Microalgal abundance in congelation ice decreases with increasing distance from the ice-seawater interface (Fig. 3; Grossi \& Sullivan 1985) and bacterial growth is stimulated by microalgal blooms in congelation ice (Grossi et al. 1984). Thus, more actively growing bacteria are likely to occur in the bottom $5 \mathrm{~cm}$ of congelation ice than at greater distances from the ice-seawater interface.

Despite obvious differences between assumptions used to estimate sea ice bacterial growth, the estimates were similar for sea ice with 0 to $5 \mathrm{~cm}$ snow cover from mid-November to mid-December, with the exception of snow-free congelation ice, which showed no significant net bacterial accumulation (Table 2). Although not as rigorous a comparison of ${ }^{3} \mathrm{H}$-thymidine incorporation and bacterial growth as advocated by Ducklow \& Hill (1985), this suggests that the rate of ${ }^{3} \mathrm{H}$-thymidine incorporation may be a reasonable but conservative estimate of net bacterial growth in sea ice. Bacterial growth determined from either estimate was similar to other estimates of growth for bacterioplankton of the Southern Ocean (Table 3) and bacteria in congelation ice (Grossi et al. 1984).

Thymidine incorporation per cell was calculated to obtain an index of the average physiological state of bacteria (Wright 1978, Fuhrman et al. 1980) and to correlate with other factors related to bacterial growth. This index increased throughout the study, indicating a seasonal increase in the rate of bacterial growth in the sea ice. Although thymidine incorporation per cell presumably reflects growth rate, these results may also be due to differences in intracellular pool sizes of thymidine, percent of radioactive TCA-insoluble material that is DNA, thymidine content of the DNA, amount of DNA per bacterium, or percent of bacteria incorporating ${ }^{3} \mathrm{H}$-thymidine, as Ducklow \& Kirchman (1983) and Riemann et al. (1984) have pointed out. Specific rates of thymidine incorporation approached $10^{-21}$ moles thymidine cell ${ }^{-1} \mathrm{~h}^{-1}$ anly from late 
Table 3. Estimates of bacterial abundance, biomass, production, and specific growth rates for various regions of the Southern Ocean. Bacterial production expressed as percentage of primary production by phytoplankton or sea ice microalgae. All estimates of bacterial production based upon ${ }^{3} \mathrm{H}$-thymidine incorporation except Hanson et al. (1983b) who used frequency of dividing cells (FDC). \% PP: \% of primary production; ND: no data; NM: not measurable; Iit. extrapol.: extrapolated from the literature; ${ }^{\prime}$ estimated from brine volume only; ${ }^{\prime}$ derived from bacterial cell production data

\begin{tabular}{|c|c|c|c|c|c|c|}
\hline \multirow[b]{2}{*}{ Region/Sample/Time } & \multicolumn{3}{|c|}{ Bacterial production } & \multicolumn{2}{|c|}{ Bacterial biomass } & \multirow[b]{2}{*}{ Source } \\
\hline & $\begin{array}{l}(\mathrm{mgC} \\
\left.\mathrm{m}^{-3} \mathrm{~d}^{-1}\right)\end{array}$ & $\mu\left(d^{-1}\right)$ & $\% \mathrm{PP}$ & $\begin{array}{l}(\mathrm{mg} \mathrm{C} \\
\left.\mathrm{m}^{-3}\right)\end{array}$ & $\begin{array}{c}\left(10^{12} \text { cells }\right. \\
\left.\mathrm{m}^{-3}\right)\end{array}$ & \\
\hline \multicolumn{7}{|l|}{ Drake Passage } \\
\hline $\begin{array}{l}\text { Subantarctic and polar front } \\
\text { zones (Jan) }\end{array}$ & $0.0002-0.05$ & ND & ND & ND & $0.01-0.2$ & Hanson et al. 1983a \\
\hline Subantarctic zone & 2.6 & 0.8 & lit. extrapol. & $\mathrm{ND}$ & 0.4 & Hanson et al. 1983b \\
\hline $\begin{array}{l}\text { Water adjacent pack ice } \\
\text { Antarctic zone (Sep-Oct) }\end{array}$ & 17.1 & 2.1 & $15-45$ & ND & 0.5 & Hanson et al. 1983b \\
\hline \multicolumn{6}{|l|}{ Scotia Sea } & Azam et al. 1981 \\
\hline \multicolumn{7}{|l|}{$\begin{array}{l}\text { Weddell Sea } \\
\text { Bacterioplankton (Nov-Dec) }\end{array}$} \\
\hline $\begin{array}{l}\text { Open water north of ice } \\
\text { edge zone }\end{array}$ & $0.09-0.1$ & $0.03-0.05$ & $1-8$ & $2.4-3.6$ & 0.3 & $\begin{array}{l}\text { Miller et al. } 1984 \\
\text { Krempin } 1985\end{array}$ \\
\hline $\begin{array}{l}\text { Water adjacent ice edge } \\
\text { zone }\end{array}$ & $0.1-3.0$ & $0.3-0.6$ & $16-76$ & $2.8-4.6$ & $0.2-0.3$ & $\begin{array}{l}\text { Miller et al. } 1984 \\
\text { Krempin } 1985\end{array}$ \\
\hline Beneath pack ice & $0.9-1.2$ & $0.2-0.3$ & $1-8$ & $3.7-5.7$ & $0.2-0.3$ & $\begin{array}{l}\text { Miller et al. } 1984 \\
\text { Krempin } 1985\end{array}$ \\
\hline \multicolumn{7}{|l|}{$\begin{array}{l}\text { Ross Sea (McMurdo Sound) } \\
\text { Sea ice bacteria in snow-free } \\
\text { sea ice at McMurdo station } \\
\text { (Oct-Dec) }\end{array}$} \\
\hline $\begin{array}{l}\text { Congelation ice (bottom } \\
0.05 \mathrm{~m} \text { ) }\end{array}$ & $\mathrm{NM}-24.4$ & NM-0.2 & NM-9 & $21.8-43.6$ & $\begin{array}{r}0.1-0.5 \\
(2.0-9.8)^{*}\end{array}$ & Present study \\
\hline Platelet ice $(0.43-0.45 \mathrm{~m})$ & $0.0004-0.3$ & $0.002-0.1$ & $0.009-0.01$ & 0.8 & $0.05-0.4$ & Present study \\
\hline $\begin{array}{l}\text { Bacterioplankton beneath sea } \\
\text { ice at McMurdo station } \\
\text { (Nov-Jan) } \\
\text { (Dec-Jan) }\end{array}$ & $\begin{array}{c}0.005-0.1 \\
0.05-6.0\end{array}$ & $\begin{array}{c}0.002-0.05 \\
0.1-0.6^{\cdots}\end{array}$ & $\begin{array}{l}0.08-0.2 \\
\text { ND }\end{array}$ & $\begin{array}{c}0.6-4.7 \\
3.1-12.9\end{array}$ & $\begin{array}{c}0.02-0.3 \\
0.2-1.0\end{array}$ & $\begin{array}{l}\text { Present study } \\
\text { Fuhrman \& Azam } \\
1980\end{array}$ \\
\hline
\end{tabular}

November to mid-December, making them comparable to those determined for bacterioplankton from different regions of the marine environment (Hanson et al. 1983a). Thymidine incorporation per cell was not correlated to total bacterial number, which is similar to results reported for bacterioplankton of the Southem California Bight (Fuhrman et al. 1980) and Drake Passage (Hanson et al. 1983a). Interactions between bacteria such as competition or cooperation apparently did not determine bacterial growth in sea ice, suggesting there was density-independent bacterial growth. One explanation for density-independent bacterial growth is the presence of diverse metabolic or physiological states for sea ice bacteria as proposed for oceanic bacteria (Hanson et al. 1983a). This seems probable given the diverse morphologies (and presumably physiologies) observed (Sullivan \& Palmisano
1984) and differences in microenvironments for growth between epiphytic and free-living bacteria (Grossi et al. 1984).

Bacterial production was a maximum of $9 \%$ of microalgal production in sea ice (Table 3 ). This is lower than the 8 to $76 \%$ reported for bacterioplankton of the Southern Ocean and 33 to $75 \%$ reported for bacterioplankton of coastal waters and the open ocean (Ducklow 1983). Bacterial production may be a more substantial fraction of primary production in sea ice at other times of the year. During the 1985 Wintercruise of the R/V Polar Duke, bacterial production exceeded primary production in sea ice and water column in some regions (Kottmeier \& Sullivan unpubl.). Bacterial production during the winter was presumably supported by previous primary production and DOM.

The rate of bacterial production also lagged behind 
primary production in sea ice. Based on regressing production rates to zero, there was a lag of $10 \mathrm{~d}$ in snow-free congelation ice and $26 \mathrm{~d}$ in congelation ice covered with $5 \mathrm{~cm}$ of snow, between onset of primary production and subsequent onset of bacterial production. This supports our earlier finding that growth of bacteria in congelation ice is stimulated by blooms of microalgae (Grossi et al. 1984).

Significant correlations found between bacterial production (cell, biomass, and thymidine incorporation per cell) and growth rates, and microalgal biomass, production, and growth rates suggest potential coupling of microalgal photosynthetic metabolism and bacterial growth in sea ice as we hypothesized in a previous report (Grossi et al. 1984). These results support the broad positive correlation that has been found between bacterial abundance or metabolism and primary production (Hobbie \& Rublee 1977, Azam et al. 1983). They also support the model of Smith et al. (1977), which proposes that bacteria transport and grow on dissolved extracellular organic carbon (EOC) that leaks from healthy phytoplankton during photosynthesis.

The sea ice is an excellent environment to study potential coupling of microalgal metabolism and bacterial growth. Microalgae and bacteria accumulate and grow in high concentrations (typical of cultures) within the confines of brine pockets in congelation ice and in interstitial water and on ice crystals in the platelet layer. Thus, cell microzones are closer for interaction than in the water column. In addition, electron micrographs have revealed close association between epiphytic bacteria and ice microalgae, demonstrating a physical as well as a chemical coupling between algae and bacteria (Sullivan \& Palmisano 1984). We have proposed that sea ice microalgae may provide bacteria with DOM, either dissolved photosynthate and/or extracellular polymeric substances; the bacteria may in turn provide the microalgae with vitamins and/or recycled inorganic nutrients (Grossi et al. 1984). Based on a remineralization efficiency of $50 \%$, however, bacterial production at the peak of primary production in November would remineralize much less than $1 \%$ of the daily nitrogen and phosphorus required for microalgal growth. Nitrogen and phosphorus requirements for microalgal growth could still be met by dissolved concentrations found in seawater. Bacterial remineralization may become more important later in the bloom when bacterial production increases up to 3 orders of magnitude.

The low correlation between bacterial production and microalgal primary production may be due to several factors. A lag was observed between the rates of bacterial and algal production. Bacteria in sea ice may depend upon microalgae as sources of carbon and energy for growth, but other microalgal products may contribute to inhibition of bacterial growth (Sullivan et al. 1985). Thus, bacterial growth dynamics in sea ice may reflect both positive and negative feedback relations with microalgae.

Low bacterial production in sea ice may be due to one or more of the following: release of compounds inhibitory to bacterial growth by microalgae; quantitative and qualitative changes in EOC released by microalgae affecting the pool of DOM utilized by bacteria; and potential bactivory. Antibacterial or bacteriostatic compounds may have been released by sea ice microalgae that inhibited bacterial growth as found for some phytoplankton (Steemann-Nielsen 1955, Bell et al. 1974). If sea ice bacteria were shifting-up to log phase of growth (sensu Kjeldgaard et al. 1958), then they would be more susceptible to antibacterial compounds than if in stationary or late log phases of growth (Yetka \& Wiebe 1974). The prolonged low rate of bacterial production versus primary production in the sea ice may reflect continual inhibition of bacterial growth over the $2 \frac{1}{2}$ mo of the study.

Since phytoplankton production is the ultimate source of organic matter for bacterial metabolism and growth (Williams 1984), changes in the release and composition of EOC by phytoplankton have been suggested as being important to microheterotrophs (Iturriaga 1981, Griffiths et al. 1982). Labile photosynthate is released by some phytoplankton as nutrients are depleted at the end of a bloom; the fraction released is in inverse proportion to the concentration of the limiting nutrient (Joiris et al. 1982, Azam et al. 1983, Lancelot 1983, Bratbak \& Thingstad 1985). Larsson \& Hagström (1982) proposed that $50 \%$ of the energy necessary for bacterial growth is derived from phytoplankton exudates. In the present study we found that less than $1 \%$ of microalgal fixed carbon was released as EOC (Grossi 1985). Palmisano \& Sullivan (1985a) found $4 \%$ release for microalgae of the platelet ice layer during the 1983 bloom and in 1985 Palmisano found 4 to $10 \%$ of fixed carbon was released (pers. comm.). These low amounts of EOC, while falling within the range of 1 to $16 \%$ reported for temperate phytoplankton (Williams \& Yentsch 1976, Smith et al. 1977, Larsson \& Hagström 1982, Lancelot 1983), may not support more substantial bacterial production in the sea ice. Assuming a $50 \%$ efficiency of bacterial utilization of DOM (Fuhrman \& Azam 1982, Ducklow 1983) and a maximum bacterial carbon production of $9 \%$ of primary production, bacteria would consume a maximum of $18 \%$ of the total fixed carbon in sea ice, more than the estimated amount of EOC supplied by microalgae.

In addition to the low amount of EOC released, the quality of EOC released may not have been favorable 
for more substantial bacterial growth in sea ice. A significant correlation has been found between the rate of release of large extracellular metabolites by phytoplankton and exoenzymatic activity of bacterial populations (Lancelot 1984). Recent work suggests that when phytoplankton excrete compounds of low mineral content such as carbohydrates, bacterial growth will require concomitant uptake of dissolved phosphate and/or nitrogen compounds for synthesis of bacterial biomass (Bratbak \& Thingstad 1985). Bottom congelation ice microalgae, hypothesized to be in the later stages of a bloom, senescent, and/or nitrogenlimited, incorporate a high percentage of carbon fixed from photosynthesis into a polysaccharide fraction (Palmisano \& Sullivan 1985a, M. Lizotte pers. comm.). This fraction is composed of a $(1 \rightarrow 3)$-glucan resembling the reserve $(1 \rightarrow 3)-B-D$-glucan of cultured diatoms (McConville et al. 1985). The rate of release of polysaccharides such as this, and supply of potentially limiting mineral nutrients, may play significant roles in control of bacterial growth in sea ice during the microalgal bloom.

Bactivory and herbivory by protozoans, including ciliates, choanoflagellates, heterotrophic flagellates and dinoflagellates, tintinnids, and amoebae (Fenchel \& Lee 1972, Garrison et al. 1984, 1986) should also contribute to the pool of DOM and mineral nutrients in sea ice, similar to their contribution in seawater (Andersson et al. 1985, Taylor et al. 1985). Although protozoans were rarely seen in prepared slides stained with DAPI, G. T. Taylor (pers. comm.) observed by Utermöhl settling technique numerous amoebae and ciliates in samples of congelation ice taken late in the bloom in January 1983. Since bacterial number remained constant from mid-November to midDecember in snow-free congelation ice, indicating steady-state growth, there must have been a sink for the daily input of 0.3 to $8.6 \%$ of the bacterial standing crop estimated from ${ }^{3} \mathrm{H}$-thymidine incorporation. This indirectly suggests that bactivory may have limited bacterial number in snow-free congelation ice as others have proposed for seawater (Fuhrman \& Azam 1980, Fenchel 1982, Azam et al. 1983, Ducklow 1983, Ducklow \& Kirchman 1983, Sieburth 1984, Andersen \& Fenchel 1985).

The results of this study expand our earlier work which indicated that growth of bacteria in congelation ice was stimulated by the microalgal bloom, which in turn was triggered primarily by light (Grossi et al. 1984). The phycosphere concept of Bell \& Mitchell (1972) should now be enlarged to include both the layer of loosely consolidated platelet ice and hard congelation ice. Although bacterial biomass and production were only a small fraction of microalgal biomass and primary production during logarithmic growth of microalgae in sea ice, they were equivalent to integrated bacterial biomass and production in several meters of underlying seawater. The rate of bacterial production lagged behind but was significantly correlated to primary production, suggesting that bacterial growth was coupled to photosynthetic metabolism. We propose that both the timing and amount of bacterial production in sea ice are highly dependent upon the growth phase of microalgae, the quantity and quality of compounds in the DOM pool available for bacterial growth, rates of bactivory and herbivory, and retention of the consolidated platelet layer and bottom layer of congelation ice. Further investigation into the fate of this bacterial production, particularly during the decline of the microalgal bloom and melting of sea ice, are needed to determine the dynamics of the 'microbial loop' in sea ice and clarify the potential for 'seeding' of the water column with actively growing sea ice bacteria.

Acknowledgements. The authors thank Dr. A. C. Palmisano for field assistance, Drs. R. Moe and G. Taylor for obtaining samples of platelet ice and placing experiments for in situ incubation by SCUBA diving, Dr. R. Iturriaga, Mr. M. Lizotte, 3 anonymous reviewers for critically reviewing the manuscript, and the U.S. Naval Support Force in Antarctica and ITT, Antarctic Services, Inc. for logistical support. This study was supported by National Science Foundation grant DPP 8117237 to CWS.

\section{LITERATURE CITED}

Ackley, S. F., Buck, K. R., Taguchi, S. (1979). Standing crop of algae in the sea ice of the Weddell Sea region. Deep Sea Res. 26A: 269-281

Andersen, P., Fenchel, T. (1985). Bactivory by microhetero trophic flagellates in seawater samples. Limnol. Oceanogr. 30 (1): 198-202

Andersson, A., Lee, C., Azam, F., Hagström, A. (1985) Release of amino acids and inorganic nutrients by heterotrophic marine microflagellates. Mar. Ecol. Prog. Ser 23: 99-106

Azam, F., Ammerman, J. W., Cooper, N. (1981). Bacterioplankton distributional patterns and metabolic activities in the Scotia Sea. Antarct. J. U.S. 16: 164-165

Azam, F., Fenchel, T., Field, J. G., Gray, J. S., Meyer-Reil, L. A., Thingstad, F. (1983). The ecological role of watercolumn microbes in the sea. Mar. Ecol. Prog. Ser. 10 257-263

Bell, W., Mitchell, R. (1972). Chemotactic and growth responses of marine bacteria to algal extracellular products. Biol. Bull. mar biol. Lab., Woods Hole 143: 265-277

Bell, W. H., Lang, J. M., Mitchell, R. (1974). Selective stimulation of marine bacteria by algal extracellular products. Limnol. Oceanogr. 19: 833-839

Bratbak, G., Dundas, I. (1984). Bacterial dry matter content and biomass estimations. Appl. environ. Microbiol. 48: $755-757$

Bratbak, G., Thingstad, T F. (1985). Phytoplankton-bacteria interactions: an apparent paradox? Analysis of a model system with both competition and commensalism. Mar. Ecol. Prog. Ser. 25: 23-30 
Bunt, J. S. (1971). Microbial productivity in polar regions. Symposia of the Society for General Microbiology XXI Microbes and Biological Productivity, p. 333-354

Bunt, J. S., Wood, E. J. F. (1963). Microalgae and Antarctic sea-ice. Nature, Lond. 199 (4900): 1254-1255

Bunt, J. S., Lee, C. C. (1970). Seasonal primary production in Antarctic sea ice at McMurdo Sound in 1967. J. mar. Res. 28 (3): $304-320$

Ducklow, H. W. (1983). Production and fate of bacteria in the ocean. Bioscience 33: 494-501

Ducklow, H. W., Hill, S. M. (1985). Tritiated thymidine incorporation and the growth of heterotrophic bacteria in warm core rings. Limnol. Oceanogr. 30 (2): 260-272

Ducklow, H. W., Kirchman, D. L. (1983). Bacterial dynamics and distribution during a spring diatom bloom in the Hudson River plume, USA. J. Plankton Res. 5 (3): 333-355

Eppley, R. W. (1972). Temperature and phytoplankton growth in the sea. Fish. Bull. U.S. 70 (4): 1063-1085

Fenchel, T. (1982). Ecology of heterotrophic microflagellates. IV. Quantitative occurrence and importance as bacterial consumers. Mar. Ecol. Prog. Ser. 9: 35-42

Fenchel, T., Lee, C. C. (1972). Studies on ciliates associated with sea ice from Antarctica. I. The nature of the fauna. Arch. Protistenk. 114: 231-236

Fuhrman, J. A., Azam, F. (1980). Bacterioplankton secondary production estimates for coastal waters of British Columbia, Antarctica, and California. Appl. environ. Microbiol. 39: 1085-1095

Fuhrman, J. A., Azam, F. (1982). Thymidine incorporation as a measure of heterotrophic bacterioplankton production in marine surface waters: evaluation and field results. Mar. Biol. 66: 109-120

Fuhrman, J. A., Ammerman, J. W., Azam, F. (1980). Bacterioplankton in the coastal euphotic zone: distribution, activity and possible relationships with phytoplankton. Mar. Biol. 60: 201-207

Garrison, D. L., Buck, K. R., Silver, M. W. (1984). Microheterotrophs in the ice-edge zone. Antarct. J. U.S. 19 (5): 109-111

Garrison, D. L., Sullivan, C. W., Ackley, S. F. (1986). Sea ice microbial community studies in the Antarctic. Bioscience: 36: $243-250$

Golden, K. M., Ackley, S. F. (1981). Modeling of anisotropic electromagnetic reflection from sea ice. J. geophys. Res. 86 (C9): 8107-8116

Griffiths, R. P., Caldwell, B. A., Morita, R. Y (1982). Seasonal changes in microbial heterotrophic activity in subarctic marine waters as related to phytoplankton primary productivity. Mar. Biol. 71: 121-127

Grossi, S. M. (1985). Response of a sea ice microalgal community to a gradient in under-ice irradiance. Ph.D. dissertation. Univ. of Southern California, Los Angeles

Grossi, S. M., Sullivan, C. W. (1985). Sea ice microbial communities. $V$. The vertical zonation of diatoms in an Antarctic fast ice community. J. Phycol. 21: 401-409

Grossi, S. M., Kottmeier, S. T., Sullivan, C. W. (1984). Sea ice microbial communities. III. Seasonal abundance of microalgae and associated bacteria, McMurdo Sound, Antarctica. Microb. Ecol. 10: 231-242

Grossi, S. M., Kottmeier, S. T., Moe, R. L., Taylor, G. T., Sullivan, C. W. (1987). Sea ice microbial communities. VI. Growth and primary production in bottom ice under graded snow cover. Mar. Ecol. Prog. Ser. 35: 153-164

Hanson, R. B., Lowery, H. K., Shafer, D., Sorocco, R, Pope, D. H. (1983a). Microbes in Antarctic waters of the Drake Passage: vertical patterns of substrate uptake, productivity and biomass in January 1980. Polar Biol. 2: 179-188
Hanson, R. B., Shafer, D., Ryan, T., Pope, D. H., Lowery, H. K. (1983b). Bacterioplankton in Antarctic ocean waters during late austral winter: abundance, frequency of dividing cells, and estimates of production. A.ppl environ. Microbiol. 45: 1622-1632

Hobbie, J. E., Rublee, P. (1977). Radioactive studies of heterotrophic bacteria in aquatic ecosystems. In: Cairns, J. (ed.) Aquatic microbial communities. Garyland Publ., New York, p. 441-476

Horner, R. A. (1976). Sea ice organisms. Oceanogr, mar. Biol A. Rev. 14: 167-182

Hoshiai, T (1981). Proliferation of ice algae in the Syowa Station area, Antarctica. Mem. Nat. Inst. Polar Res. Ser, E. No. 34, p. $1-12$

lizuka, H., Tanabe, I., Meguro, H. (1966). Microorganisms in plankton-ice of the Antarctic Ocean. J. gen. appl. Microbiol., Tokyo 12 (1): 101-102

Iturriaga, R. (1981). Phytoplankton photoassimilated extracellular products; heterotrophic utilization in marine environments. Kieler Meeresforsch. (Sonderh.) 5: 318-324

Joiris, C., Billen, G., Lancelot, C., Daro, M. H., Mommaerts, J. P., Bertels, A., Bossicart, M., Nijs, J., Hecq, J. H. (1982). A budget of carbon cycling in the Belgian coastal zone. Relative roles of zooplankton, bacterioplankton and benthos in the utilization of primary production. Neth. J. Sea Res. 16: 260-275

Kaneko, T., Atlas, R. M., Krichevsky, M. (1977). Diversity of bacterial populations in the Beaufort Sea. Nature, Lond. 270: $596-599$

Kjeldgaard, N. O., Maaloe, O., Schaechter, M. (1958). The transition between different physiological states during balanced growth of Salmonella typhimurium. J. gen. Microbiol. 19: 607-616

Kobori, H., Sullivan, C. W., Shizuya, H. (1984). Bacterial plasmids in Antarctic natural microbial assemblages. Appl. environ. Microbiol. 48: 515-518

Kottmeier, S. T., Muscat, A. M., Craft, L. L., Kastendiek, J. E. Sullivan, C. W. (1984). Ecology of sea-ice microbial communities in McMurdo Sound, Antarctica, in 1983. Antarct. J. U.S. 19 (5): 129-131

Kottmeier, S. T., Miller, M. A., Lizotte, M. P., Craft, L. L. Gulliksen, B., Sullivan, C. W. (1985). Ecology of sea ice microbial communities (SIMCO) during the 1984 winter to summer transition in McMurdo Sound, Antarctica Antarct. J. U.S. 20 (5): 128-130

Krempin, D. W. (1985). The role of bacterioplankton as producers in two high-productivity marine ecosystems. Ph.D. dissertation. Univ. of Southern California, Los Angeles

Lake, R. A., Lewis, E. L. (1970). Salt rejection by sea ice during growth. J. geophys. Res. 75 (3): 583-597

Lancelot, C. (1983). Factors affecting phytoplankton extracellular release in the Southern Bight of the North Sea. Mar. Ecol. Prog. Ser. 12: 115-121

Lancelot, C. (1984). Metabolic changes in Phaeocystis pouchetii (Hariot) Lagerheim during the spring bloom in Belgian coastal waters. Estuar. coast. Shelf Sci. 18: $593-600$

Larsson, U., Hagström, А. (1982). Fractionated phytoplankton primary production, exudate release and bacterial production in a Baltic eutrophication gradient. Mar. Biol. 67: $57-70$

Littlepage, J. (1965). Oceanographic investigations in McMurdo Sound, Antarctica. Antarct. Res. Ser. 5: 1-37

Marra, J., Burckle, L. H., Ducklow, H. W. (1982). Sea ice and water column plankton distributions in the Weddell Sea in late winter. Antarct. J. U.S. 17: 111-112

McConville, M. J., Wetherbee, R. (1983). The bottom-ice 
microalgal community from annual ice in the inshore waters of East Antarctica. J. Phycol. 19: 431-439

McConville, M. J., Mitchell, C., Wetherbee, R. (1985) Patterns of carbon assimilation in a microalgal community from annual sea ice, East Antarctica. Polar Biol. 4: 135-141

Miller, M. A., Krempin, D. W., Manahan, D. T., Sullivan, C. W. (1984). Growth rates, distribution, and abundance of bacteria in the ice-edge zone of the Weddell and Scotia Seas, Antarctica. Antarct. J. U.S. 19 (5): 103-105

Morita, R. Y. (1975). Psychrophilic bacteria. Bact. Rev. 29: $144-167$

Palmisano, A. C., Sullivan, C. W. (1985a). Pathways of photosynthetic carbon assimilation in sea-ice microalgae from McMurdo Sound, Antarctica. Limnol. Oceanogr. 30 (3): $674-678$

Palmisano, A. C., Sullivan, C. W. (1985b). Growth, metabolism, and dark survival in sea ice microalgae. In: Horner, R. A. (ed.) Sea ice biota. CRC Press, Inc., Boca Raton, Florida, p. 132-146

Palmisano, A. C., SooHoo, J. B., Moe, R. L., Sullivan, C. W (1987). Sea ice microbial communities. VII. Changes in under-ice spectral irradiance during the development of Antarctic sea ice microalgal communities. Mar. Ecol. Prog. Ser. 35: 165-173

Reeburgh, W. S. (1984). Fluxes associated with brine motion in growing sea ice. Polar Biol. 3: 29-33

Riemann, B., Nielsen, P., Jeppesen, M., Marcussen, B., Fuhrman, J. A. (1984). Diel changes in bacterial biomass and growth rates in coastal environments, determined by means of thymidine incorporation into DNA, frequency of dividing cells (FDC), and microautoradiography. Mar. Ecol. Prog. Ser. 17: 227-235

Rohlf, F. J., Sokal, R. R. (1969). Statistical tables. W. H. Freeman, San Francisco

Sieburth, J. McN. (1984). Grazing of bacteria by protozooplankton in pelagic marine waters. In: Hobbie, J. E. Williams, P. J. leB. (ed.) Heterotrophic activity in the sea. Plenum Press, New York, p. 405-444

Smith, W. O., Barber, R. T., Huntsman, S. A. (1977). Primary production off the coast of northwest Africa: excretion of dissolved organic matter and its heterotrophic uptake. Deep Sea Res. 24: 35-47

Sokal, R. R., Rohlf, F. J. (1981). Biometry. 2nd edn. W. H. Freeman, San Francisco

Steemann-Nielsen, E. (1955). The production of antibiotics by planktonic activity and its effect upon bacterial activity in the sea. Deep Sea Res. 3 (Suppl.): 281-286

Strickland, J. D. H., Parsons, I R. (1972). A practical handbook of seawater analysis. 2nd edn. Bull. Fish. Res. Bd Can. 167

Sullivan, C. W. (1985). Sea ice bacteria: reciprocal interactions of the organisms and their environment. In: Horner,
R. A. (ed.) Sea ice biota. CRC Press, Inc, Boca Raton, Florida, p. 159-171

Sullivan, C. W., Palmisano, A. C. (1981). Sea-ice microbial communities in McMurdo Sound. Antarct. J. U.S. 16: $126-127$

Sullivan, C. W., Palmisano, A. C. (1984). Sea ice microbial communities: distribution, abundance, and diversity of ice bacteria in McMurdo Sound, Antarctica, in 1980. Appl. environ. Microbiol. 47: 788-795

Sullivan, C. W., Palmisano, A. C., Kottmeier, S., McGrathGrossi, S., Moe, R. (1985). The influence of light on growth and development of the sea-ice microbial community in McMurdo Sound. In: Siegfried, W. R., Condy, P. R., Laws, R. M. (ed.) Antarctic nutrient cycles and food webs (Proceedings of the fourth SCAR symposium on Antarctic biology). Springer-Verlag, Berin, p. 78-83

Tate, W. M., Clelland, R. C. (1957). Nonparametric and shortcut statistics. Interstate printers and publishers, Danville, Illinois

Taylor, G. T., Iturriaga, R., Sullivan, C. W. (1985), Interactions of bactivorous grazers and heterotrophic bacteria with dissolved organic matter. Mar. Ecol. Prog. Ser. 23: 129-141

Whitaker, T. M. (1977). Sea ice habitats of Signy Island (South Orkneys) and their primary productivity. In: Llano, G. A. (ed.) Adaptations within Antarctic ecosystems. Proceedings third SCAR symposium Antarctic biology. Smithsonian Institution, Washington, D.C., p. 75-82

Williams, P. J. leB. (1981). Incorporation of microheterotrophic processes into the classical paradigm of the planktonic food web. Kieler Meeresforsch. (Sonderh.) 5: 1-28

Williams, P. J. leB. (1984). Bacterial production in the marine food chain: the emperor's new suit of clothes? In: Fasham, M. J. R. (ed.) Flows of energy and materials in marine ecosystems: theory and practice. Plenum Press, New York, p. $271-299$

Williams, P. J. leB., Yentsch, C. S. (1976). An examination of photosynthetic production, excretion of photosynthetic products and heterotrophic utilization of dissolved organic compounds with reference to results from a coastal subtropical sea. Mar. Biol. 35: 31-40

Wright, R. T. (1978). Measurement and significance of specific activity in the heterotrophic bacteria of natural waters. A.ppl. environ. Microbiol. 36: 297-305

Yetka, J. E., Wiebe, W. J. (1974). Ecological application of antibiotics as respiratory inhibitors of bacterial populations. Appl. environ. Microbiol. 28: 1033-1039

Zimmerman, R. (1977). Estimation of bacterial number and biomass by epifluorescence microscopy and scanning electron microscopy. In: Rheinheimer, G. (ed.) Microbial ecology of brackish water environment. Springer-Verlag, New York, p. 103-120 